ISSN = 1980-993X - doi:10.4136/1980-993X
www.ambi-agua.net
E-mail: ambi-agua@agro.unitau.br
Tel.: (12) 3625-4212

\title{
Valores anômalos de metais pesados em solo de cemitério
}

(http://dx.doi.org/10.4136/ambi-agua.838)

\section{Pedro Daniel da Cunha Kemerich ${ }^{\mathbf{1}}$; Willian Fernando de Borba ${ }^{\mathbf{1}}$; Rodrigo Ferreira da Silva1; Guilherme Barros ${ }^{1}$; Ademir Eloi Gerhardt ${ }^{1}$; Carlos Eduardo Balestrin Flores ${ }^{1}$}

\author{
${ }^{1}$ Universidade Federal de Santa Maria \\ E-mail: eng.kemerich@yahoo.com.br; borba_willian@hotmail.com; rofesil@bol.com.br; \\ Guilherme_barrosp@hotmail.com; adegerhardt@bol.com.br; cadu-fw@hotmail.com
}

\section{RESUMO}

O necrochorume gerado pela decomposição dos corpos humanos apresenta uma carga poluidora elevada e, em virtude do local onde se encontra, poderá atingir e contaminar o solo e os recursos hídricos superficiais e subterrâneos. O problema é agravado quando as necrópoles localizam-se em áreas de vulnerabilidade considerável e a população do entorno faz uso direto dos recursos hídricos sob a influência do mesmo, estando assim sujeita à doenças de veiculação hídrica. O presente trabalho teve como objetivo analisar as concentrações dos metais pesados bário, cobre, cromo e zinco em solo ocupado por necrópole. Para coleta de solo, foram realizadas tradagens em 10 diferentes pontos e profundidades. Para determinação da concentração dos metais foi utilizada a técnica de Fluorescência de Raios-X por Energia Dispersiva e com auxílio do software Surfer 10, foram espacializados os dados gerando-se cartogramas. Os metais bário e cobre apresentaram concentrações que indicaram contaminação do solo em todos os pontos amostrados. Já a concentração do cromo apresentou indícios de contaminação em diversas profundidades entre 0 e $300 \mathrm{~cm}$. O ponto de menor cota topográfica foi o único a ter concentração de zinco acima dos valores de referência, indicando relação do fluxo superficial e sub-superficial da água com a contaminação por esse elemento. Com os resultados obtidos pode-se constatar o potencial de contaminação por metais em solo ocupado por cemitério.

Palavras chaves: Bário; cobre; cromo; necrochorume; zinco.

\section{Anomalous values of heavy metals in soil of cemetery}

\begin{abstract}
The necro chorume generated by the decomposition of human bodies has a high pollution load and depending on its location, it may reach and contaminate the soil, the surface and underground water resources. The problem is critical because the analyzed cemetery is located in a vulnerable area and the surrounding population makes use of the water under the influence of the necro chorume, and therefore, subjected to water carrying diseases. This study aimed to analyze the concentrations of heavy metals barium, copper, chromium and zinc in soil occupied by necropolis. An auger was used to collect soil samples in 10 different sites and depths. For determining the concentration of metals, the technique of fluorescence $\mathrm{X}$-ray Energy Dispersive with the support of the software Surfer 10 was used to spatially generate concentration data maps. The concentrations of barium and copper indicated contamination of the soil in all sampled sites, while the chrome showed evidence of
\end{abstract}


KEMERICH, P. D. C.; BORBA, W. F.; SILVA, R. F.; BARROS, G.; GERHARDT, A. E.; FLORES, C. E. B. Valores anômalos de metais pesados em solo de cemitério. Ambi-Agua, Taubaté, v. 7, n. 1, p. 140-156, 2012. (http://dx.doi.org/10.4136/ambi-agua.838)

contamination at various depths between 0 and $300 \mathrm{~cm}$. The lowest topographic point was the only one to have zinc concentration above reference values, indicating a contamination by this element in the surface flow and sub-surface water. With these results we can confirm the potential of metal contamination in soil occupied by the cemetery.

Keywords: Barium; copper; chromium; necrochorume; zinc.

\section{INTRODUÇÃO}

O uso de águas superficiais se torna cada vez mais problemático em virtude da precariedade dos sistemas de saneamento básico e pelo alto custo de sistemas de tratamento necessários para o atendimento aos padrões de potabilidade (Vendame et al., 2003). Nesse contexto a água subterrânea pode amenizar esse problema, pela sua boa qualidade e o solo funcionar como uma espécie de filtro retendo impurezas nela depositadas.

Em razão do crescimento desenfreado da população e pela contaminação das águas tanto superficiais quanto subterrâneas, o suprimento de água potável em regiões mais desenvolvidas torna-se cada vez mais escasso e de alto custo (Filizola et al., 2002). O solo tem um papel muito importante na retenção dos microrganismos, considerando fatores físicos e químicos, que afetam a infiltração e o carreamento dos microrganismos em direção ao lençol freático (Martins et al., 1991).

Segundo Silva e Malagutti Filho (2008), os cemitérios nunca foram incluídos nas listas de fontes tradicionais de contaminação ambiental, apesar da existência de alguns relatos históricos em Berlim e Paris na década de 70, constatando que a causa de epidemias de febre tifoide estava diretamente relacionada ao posicionamento dos cemitérios à jusante de fontes de água, como aquíferos freáticos e nascentes.

Entretanto, Silva e Malagutti Filho (2010) afirmam que a partir da resolução do Conselho Nacional do Meio Ambiente (Brasil, 2003) no 335 de 3 de abril de 2003, que dispõe sobre o licenciamento ambiental de cemitérios horizontais e verticais a serem implantados no Brasil, esses estabelecimentos passam a ser vistos como fontes de contaminação do ambiente, e sua implantação está sujeita ao atendimento dos critérios legais.

A implantação dos cemitérios, sem levar em consideração os critérios geológicos (características litológicas e estrutura do terreno) e hidrogeológicos (nível do lençol freático), constitui uma das causas de deterioração da qualidade das águas subterrâneas. Anjos (2007) afirmou que a principal causa de poluição nos cemitérios, durante a decomposição dos cadáveres, é um líquido denominado necrochorume. Esta é uma solução com concentração elevada de sais minerais e substâncias orgânicas degradáveis, de tonalidade castanhoacinzentada, viscosa, de cheiro forte e com grau variado de patogenicidade. Deste modo, como os cemitérios são considerados como um depósito de corpos humanos, estes necessitam de uma destinação correta, pois a degradação dos corpos pode se constituir em focos de contaminação.

A disposição dos corpos humanos, de forma inadequada, pode gerar problemas de poluição no aquífero subterrâneo, bem como no solo. Devido à ação das águas superficiais e das chuvas infiltradas nas sepulturas, ou pelo contato dos corpos com as águas subterrâneas, o necrochorume pode entrar em contato e contaminar estas águas (Neira et al., 2008). A toxicidade química do necrochorume diluído na água freática relaciona-se aos teores anômalos de compostos das cadeias do fósforo e do nitrogênio, metais pesados e aminas.

Com base no tema exposto, este trabalho teve como objetivo determinar o potencial de contaminação química do solo por bário, cobre, cromo e zinco em decorrência da ocupação por cemitério. 


\section{MATERIAL E MÉTODOS}

\subsection{Caracterização da área de estudo}

O município de Seberi está situado no noroeste do estado do Rio Grande do Sul (Brasil) na latitude $27^{\circ} 28^{\prime} 4^{\prime \prime} \mathrm{S}$ e longitude $53^{\circ} 24^{\prime} 09^{\prime \prime} \mathrm{O}$, com altitude de 546 metros do nível do mar, abrangendo uma área de $301 \mathrm{Km}^{2}$ e com população de 11098 habitantes, sendo o mesmo pertencente à bacia hidrográfica do Rio Uruguai com clima subtropical úmido (IBGE, 2009). O cemitério municipal São João Batista está situado a $520 \mathrm{~m}$ altitude e foi fundado no ano de 1930, contendo atualmente cerca de 3 mil sepulturas, recebendo em média 7 corpos por mês em uma área de 1,2 hectares, conforme ilustra a Figura 1. Na área estudada, existem basicamente dois tipos de sepulturas, aquelas onde os corpos estão em contato direto com solo e as outras conhecidas como jazigo, estas são construções existentes nos cemitérios executada com placas pré-moldadas onde são sepultados os corpos. Este espaço físico é composto normalmente por "gavetas", onde são depositados os corpos, que ficam normalmente a $1 \mathrm{~m}$ do solo.

\subsection{Localizações dos pontos de amostragem e coleta de amostras}

A tradagem para coleta das amostras foi realizada em função da topografia existente no cemitério e do fluxo preferencial de água superficial, determinado com o auxílio do software Surfer 10 da Golden Software, utilizando-se o método de interpolação matemática Krigagem (Figura 1). Foram considerados 10 pontos de coleta denominados: P1, P2, P3, P4, P5, P6, P7, P8, P9 e P10, conforme mostra a Figura 1, sendo que P1 encontra-se no ponto de maior elevação, sendo considerado o ponto controle. Sendo que a maior cota foi observada no ponto 1 com 522,5 m e o menor no ponto 10 a uma cota de 518,0 m.

A Figura 1 ilustra a área total do cemitério, com os pontos de amostragem e as linhas de fluxo superficial da água.

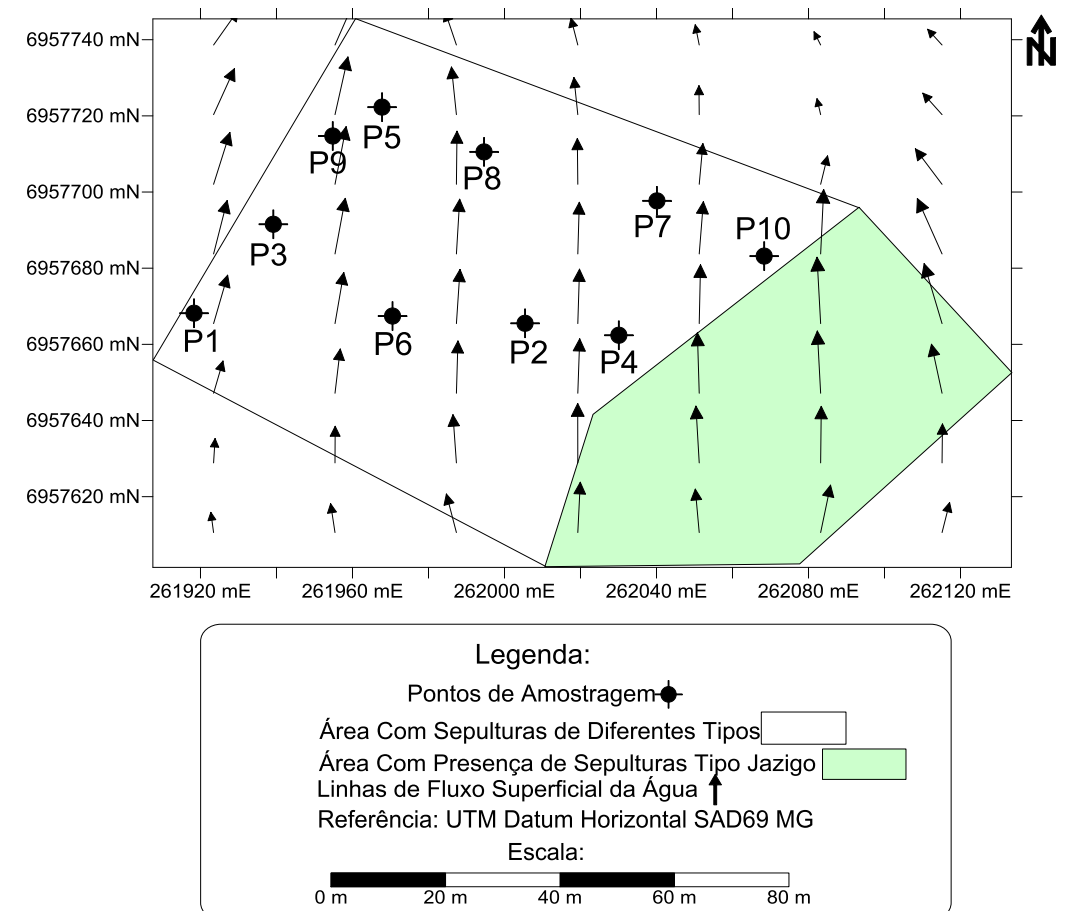

Figura 1. Cartograma da área do cemitério, com linhas de fluxo e pontos de amostragem. 
KEMERICH, P. D. C.; BORBA, W. F.; SILVA, R. F.; BARROS, G.; GERHARDT, A. E.; FLORES, C. E. B. Valores anômalos de metais pesados em solo de cemitério. Ambi-Agua, Taubaté, v. 7, n. 1, p. 140-156, 2012. (http://dx.doi.org/10.4136/ambi-agua.838)

Para a coleta das amostras foi utilizado um trado manual Sonda Terra de $4 \mathrm{~m}$ de comprimento. Cada amostra coletada foi armazenada em sacos plásticos e recebeu identificação correspondendo à localização do ponto de amostragem e a profundidade da coleta. Nos 10 pontos analisados foram coletadas amostras a cada $50 \mathrm{~cm}$ de profundidade, iniciando-se com a amostra superficial em $0 \mathrm{~cm}$ até a profundidade de $300 \mathrm{~cm}$, totalizado 7 amostras por ponto. Para evitar alterações nos resultados o trado era lavado com água destilada ao fim de cada coleta de amostra.

\subsection{Preparo de amostras e determinação de metais}

Foram pesadas $20 \mathrm{~g}$ de solo e encaminhadas para a secagem em estufa à temperatura de $105{ }^{\circ} \mathrm{C}$ por duas horas utilizando-se vidraria básica de laboratório (Becker $50 \mathrm{~mL}$ ) para sua deposição.

Após o quarteamento e a secagem em estufa as amostras foram moídas manualmente em gral com pistilo, objetivando reduzir ao máximo a granulometria da amostra reduzindo os desvios do feixe de Raios-X e assim não influenciando na eficiência das determinações.

As amostras de solo foram então comprimidas em prensa manual em matriz apropriada formando uma pastilha sólida e compacta que foi encaminhada para a análise. A pastilha foi formada usando 10 toneladas de pressão por 10 minutos. Este procedimento aglomera as partículas tornando-as um aglomerado cerâmico cujo resultado analítico reflete-se num padrão ideal para análise por EDXRF.

As análises foram realizadas utilizando um Espectrômetro de Fluorescência de Raios-X por Energia Dispersiva, do modelo Shimadzu EDX-720. As seguintes condições de operação do equipamento foram selecionadas: tensão do tubo de $15 \mathrm{keV}$ ( $\mathrm{Na}$ a $\mathrm{Sc}$ ) e $50 \mathrm{keV}$ (Ti a U) com corrente no tubo $184 \mu \mathrm{A}$ e $25 \mu \mathrm{A}$ respectivamente, colimador de $10 \mathrm{~mm}$, tempo real de integração de 200 segundos tempo morto do detector de $40 \%$ e $39 \%$, sob vácuo e detector de $\mathrm{Si}(\mathrm{Li})$ refrigerado com nitrogênio líquido. $\mathrm{O}$ método analítico usado é denominado método dos Parâmetros Fundamentais (PF) (Bona et al., 2007). Este método permite a obtenção da curva de sensibilidade do equipamento para cada elemento de interesse, quando uma amostra de composição química conhecida é submetida a parâmetros instrumentais bem definidos. A curva de sensibilidade do equipamento relaciona a intensidade fluorescente teórica calculada e a medida para cada elemento (Bona et al., 2007).

Em geral, análise quantitativa por EDXRF é realizada pelo método da curva de calibração. No entanto, para algumas aplicações é difícil obter padrões certificados suficientes, com matrizes semelhantes às amostras e, dessa forma, conseguir uma boa distribuição de pontos de dados sobre a escala de cada elemento a ser determinado. Han et al. (2006) a partir dos resultados da análise experimental de várias e diferentes amostras, comprovaram que resultados de alta precisão podem ser obtidos pelo método de $\mathrm{FP}$, mesmo que apenas amostras de elemento puro sejam utilizadas para calibração. Isso também ilustra claramente que o método FP pode corrigir efetivamente o complicado cálculo do efeito da matriz. Portanto, para análise de rotina em massa, se as amostras de calibração estão ausentes, o método FP pode fornecer resultados relativamente precisos e quantitativos.

Os valores de referência propostos pela CONAMA nº420/2009 (Brasil, 2009) para os metais analisados estão presentes na Tabela 1.

Tabela 1. Valores de referência para solos.

\begin{tabular}{c|c}
\hline Metal & $\begin{array}{c}\text { Valor de referência para solos } \\
\left(\mathbf{m g ~ k g}^{-1}\right)\end{array}$ \\
\hline Bário & 150 \\
Cobre & 60 \\
Cromo & 75 \\
Zinco & 300 \\
\hline
\end{tabular}

Fonte: Adaptado de CONAMA nº 420/2009 (Brasil, 2009). 
KEMERICH, P. D. C.; BORBA, W. F.; SILVA, R. F.; BARROS, G.; GERHARDT, A. E.; FLORES, C. E. B. Valores anômalos de metais pesados em solo de cemitério. Ambi-Agua, Taubaté, v. 7, n. 1, p. 140-156, 2012. (http://dx.doi.org/10.4136/ambi-agua.838)

Foram determinadas as concentrações totais dos metais: bário $\left(\mathrm{Ba}^{+2}\right)$, cobre $\left(\mathrm{Cu}^{+1}\right)$, cromo $\left(\mathrm{Cr}^{+1}\right)$ e zinco $\left(\mathrm{Zn}^{+2}\right)$, que possuem valor de referência propostos pela Resolução CONAMA n ${ }^{\circ} 420 / 2009$.

\section{RESULTADOS E DISCUSSÃO}

A Tabela 2 ilustra a concentração dos metais em todos os pontos e profundidades analisadas.

Tabela 2. Concentração dos metais nos pontos de amostragem.

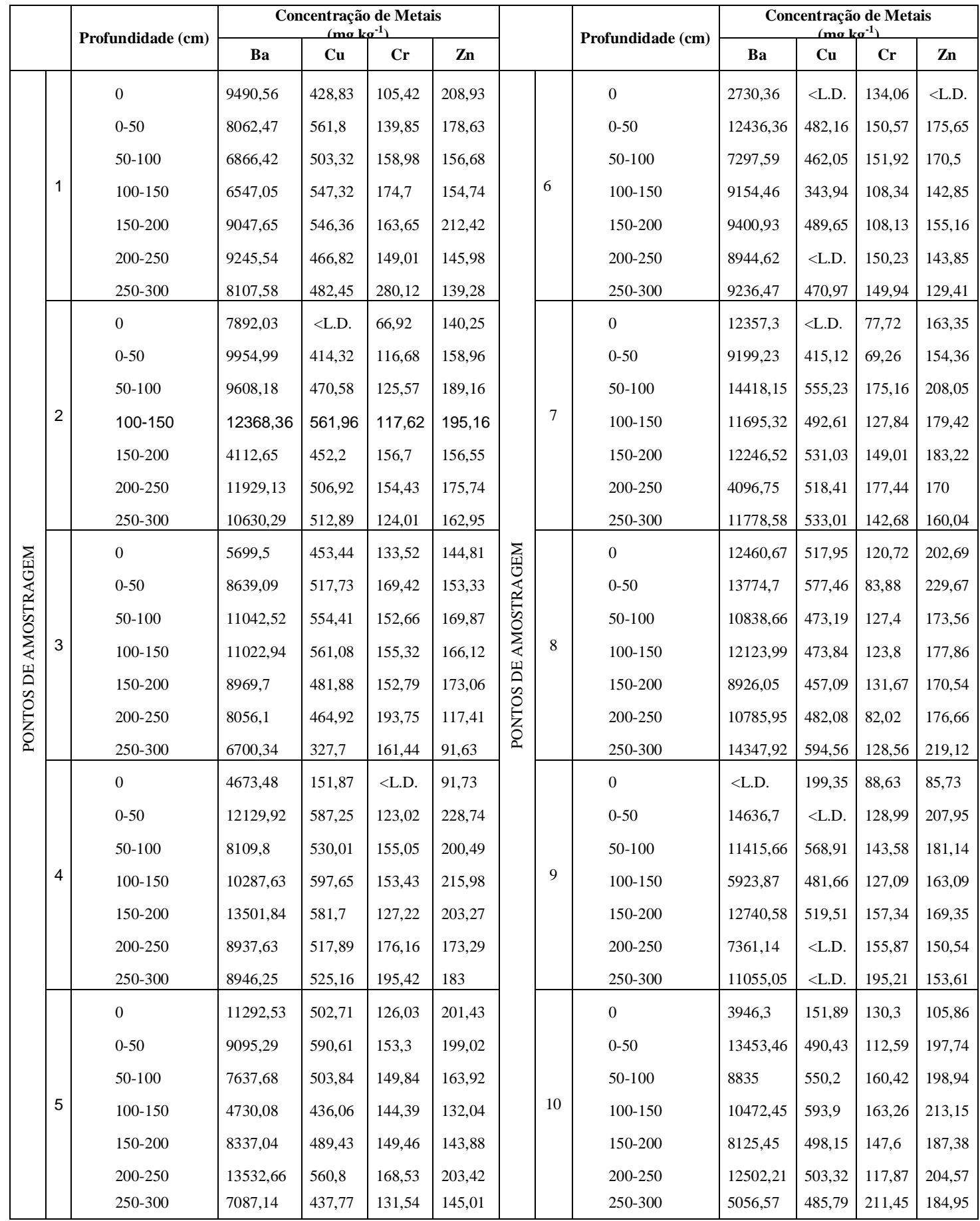


KEMERICH, P. D. C.; BORBA, W. F.; SILVA, R. F.; BARROS, G.; GERHARDT, A. E.; FLORES, C. E. B. Valores anômalos de metais pesados em solo de cemitério. Ambi-Agua, Taubaté, v. 7, n. 1, p. 140-156, 2012. (http://dx.doi.org/10.4136/ambi-agua.838)

\subsection{Bário}

A Figura 2 apresenta o comportamento do Bário na área ocupada pelo cemitério São João Batista nos pontos P1 a P10 nas profundidades 0,50 e $100 \mathrm{~cm}$. Todos os pontos amostrados, com a exceção do ponto 9 na amostra superficial $(0 \mathrm{~cm})$ apresentaram os valores acima do permitido pela Resolução CONAMA no 420 de 28 de dezembro de 2009 que estabelece o valor limite de $150 \mathrm{mg} \mathrm{kg}^{-1}$ de bário para solos. A concentração de Ba no solo, em escala mundial, varia de 19 a $2368 \mathrm{mg} \mathrm{kg}^{-1}$, podendo ser mobilizado em diferentes condições (Kabata-Pendias e Pendias, 1992). Teixeira (2003) diz que este elemento é tóxico e pode matar pela ingestão de apenas meio grama, mas felizmente, sua absorção é lenta. É usado em venenos para ratos, depilatórios, pigmentos para pintura, vidros e cerâmicas. Na medicina é usado em contrastes radiológicos para estômago, vesícula e intestinos.

Na profundidade $0 \mathrm{~cm}$ os maiores valores econtram-se na região nordeste do cartograma entretanto, o ponto 7 apresentou uma concentração semelhante ao observado a 0 e $150 \mathrm{~cm}$ de profundidade. Para a profundidade $50 \mathrm{~cm}$ os maiores valores situam-se a noroeste do cartograma. Já em $100 \mathrm{~cm}$ de profundidade os maiores valores encontram-se na região nordeste. Em $150 \mathrm{~cm}$ os menores valores encontran-se na região oeste, já os maiores valores localizam-se nas regiões nordeste e sudeste.
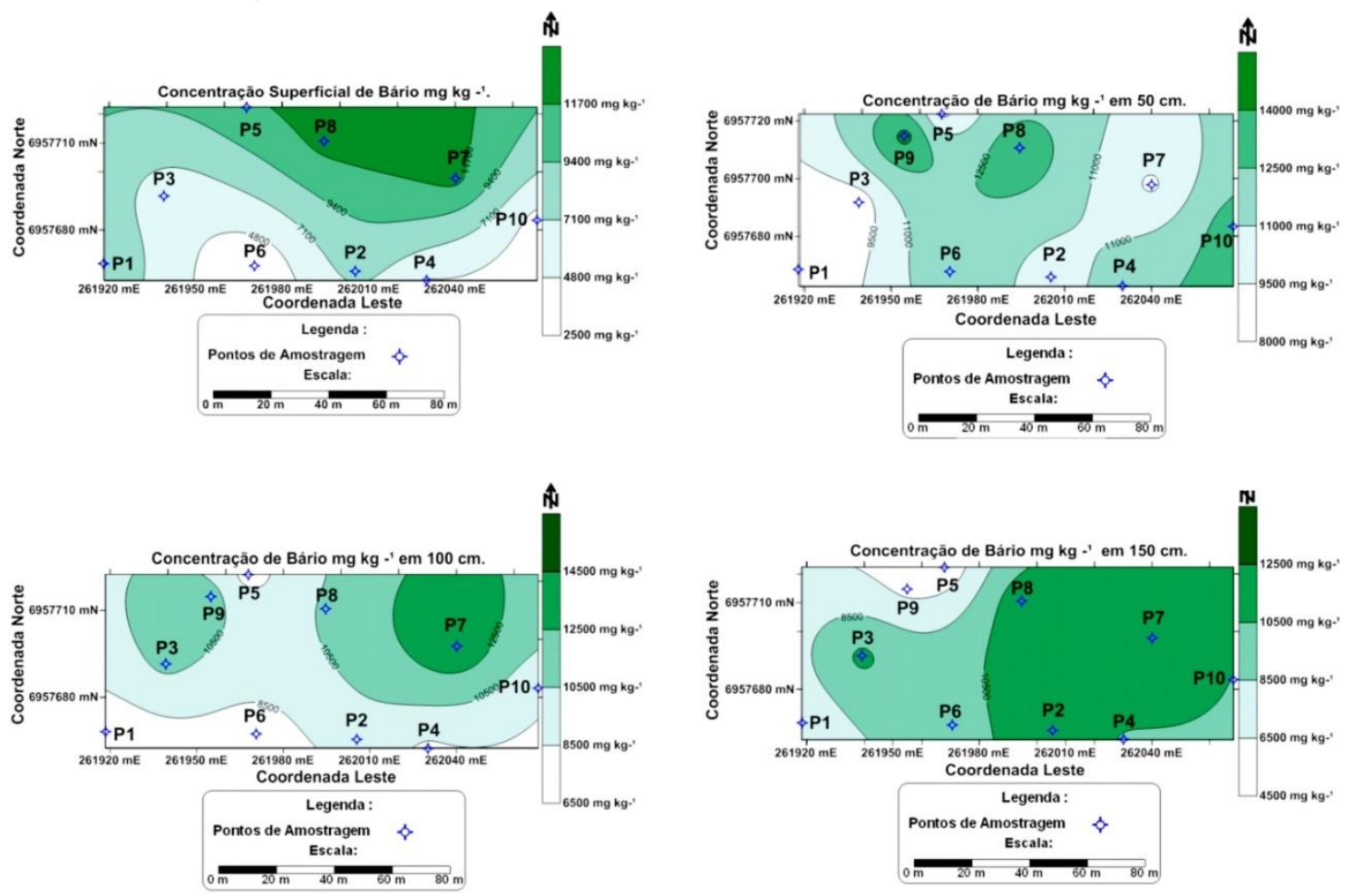

Figura 2. Concentração de Bário no Cemitério São João Batista nas profundidades entre 0 e $150 \mathrm{~cm}$.

A Figura 3 ilustra a concentração de bário nas profundidades variando de 200 a $300 \mathrm{~cm}$, profundidades essas abaixo do local onde geralmente ocorre o sepultamento no cemitério. $\mathrm{Na}$ profundidade de $200 \mathrm{~cm}$ o maior valor encontrado situa-se na região noroeste, leste e sudeste do cartograma, já os menores valores ocorreram na região sul. Na profundidade $250 \mathrm{~cm} \mathrm{o}$ bário apresentou a maior concentração com $13532,66 \mathrm{mg} \mathrm{kg}^{-1}$ no ponto $5 \mathrm{e}$ altitude de $518,738 \mathrm{~m}$, no cartograma os maiores valores estão nas regiões leste e noroeste. Os menores valores situam-se no ponto 7 a uma concentração de $4096,75 \mathrm{mg} \mathrm{kg}^{-1}$ e altitude de 520,655 $\mathrm{m}$, as menores concentrações estão presentes na região nordeste.

Na profundidade $300 \mathrm{~cm}$ tem-se como valor máximo de bário $14347,92 \mathrm{mg} \mathrm{kg}^{-1}$ no ponto 8 a uma altitude de $518,7 \mathrm{~m}$, no cartograma os maiores valores estão localizados na 
KEMERICH, P. D. C.; BORBA, W. F.; SILVA, R. F.; BARROS, G.; GERHARDT, A. E.; FLORES, C. E. B. Valores anômalos de metais pesados em solo de cemitério. Ambi-Agua, Taubaté, v. 7, n. 1, p. 140-156, 2012. (http://dx.doi.org/10.4136/ambi-agua.838)

região norte (Figura 3). A menor concentração de bário em $300 \mathrm{~cm}$ está no ponto $10 \mathrm{com}$ $5056,57 \mathrm{mg} \mathrm{kg}^{-1}$ e uma altitude de 518,0 m, os menores valores estão nas regiões leste e sul. A menor concentração encontrada para bário em todas as profundidades foi no ponto 9 a 0 $\mathrm{cm}$ e a maior no ponto $9 \mathrm{em} 50 \mathrm{~cm}$.
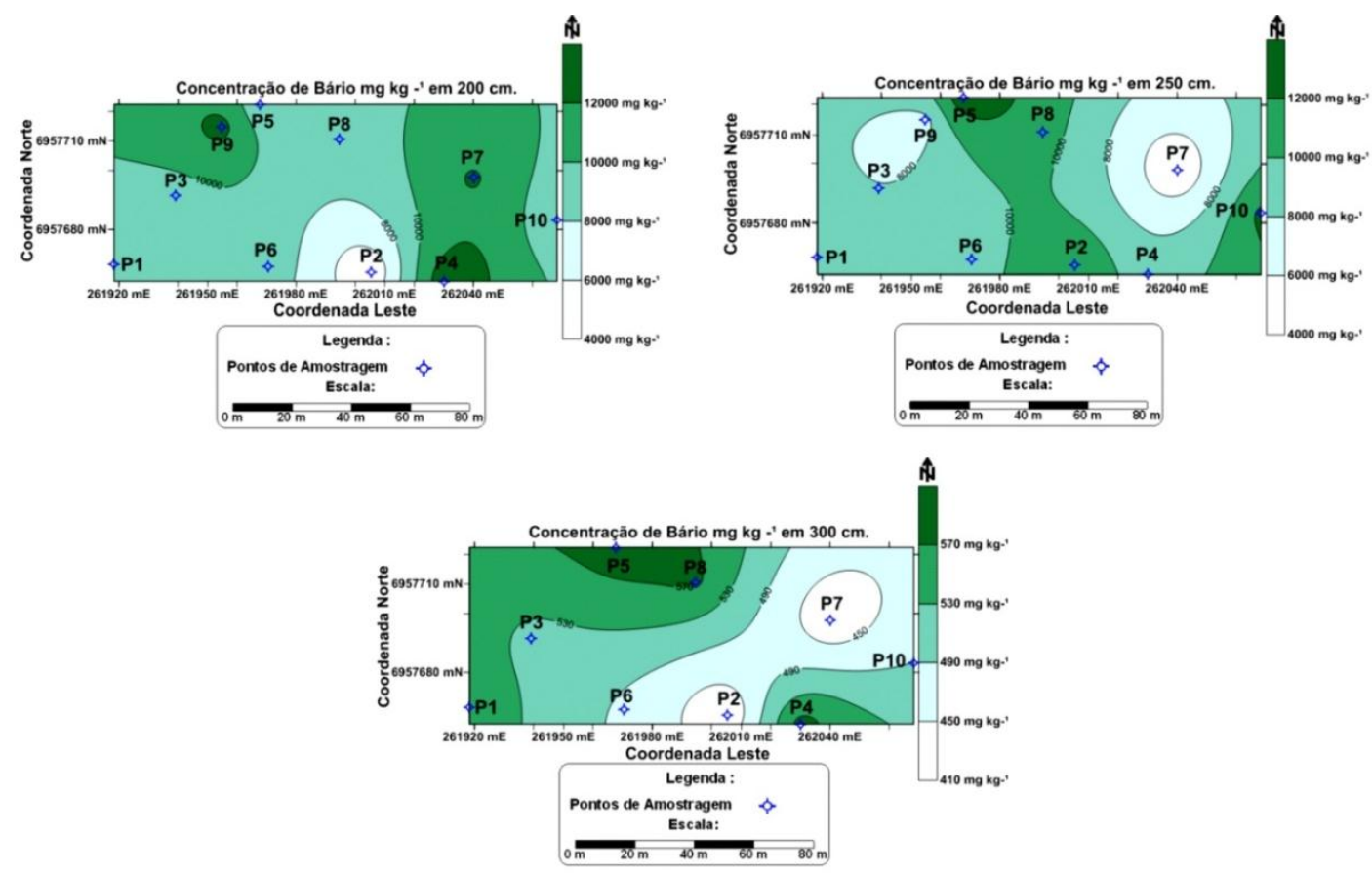

Figura 3. Concentração de Bário no Cemitério São João Batista nas profundidades entre 200 e $300 \mathrm{~cm}$.

A Figura 4 (a) ilustra a concentração média de Bário nos 10 diferentes pontos de amostragem, sendo os maiores valores médios encontrados no ponto $8 \mathrm{com}$ uma concentração que varia de 9500 a $14200 \mathrm{mg} \mathrm{kg}^{-1}$, já os menores valores médios foram encontrados no ponto 1 a uma concentração que varia de 6000 a $10500 \mathrm{mg} \mathrm{kg}^{-1}$. A Figura 4 (b) ilustra a concentração média de Bário em 7 diferentes profundidades, sendo os maiores valores médios presentes na profundidade $50 \mathrm{~cm}$ a uma concentração que varia de 9200 a $14000 \mathrm{mg} \mathrm{kg}^{-1}$, já as menores concentrações médias encontraram-se na profundidade $0 \mathrm{~cm}$ com uma variação de 5000 a $9000 \mathrm{mg} \mathrm{kg}^{-1}$.

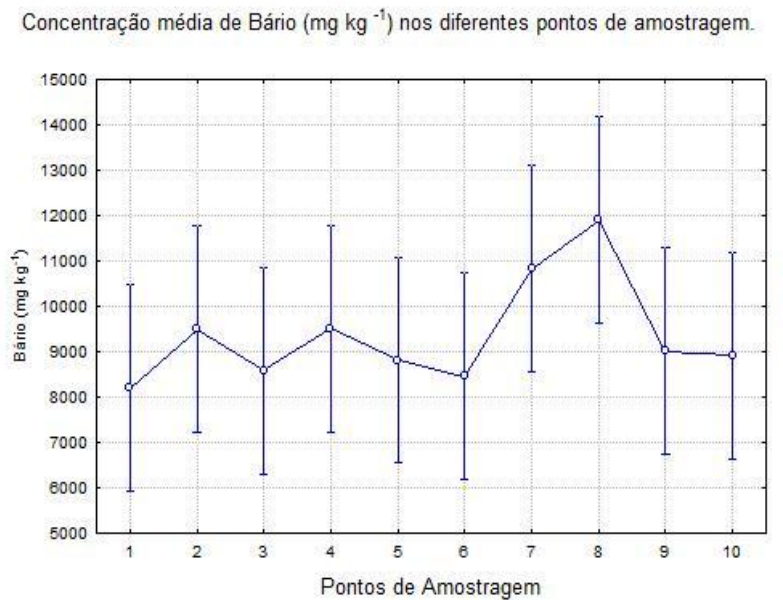

(a)

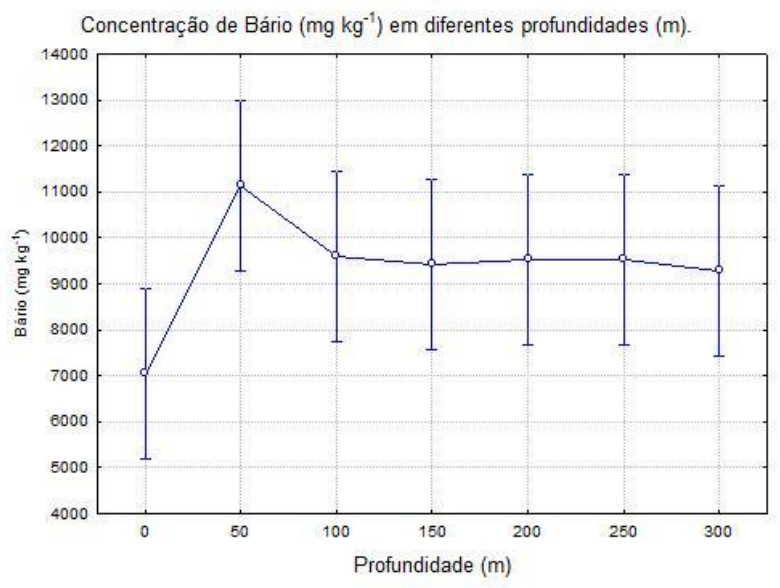

(b)

Figura 4. Concentração média de Bário em 10 pontos de amostragens (a), concentração média de Bário em 7 diferentes profundidades (b). 
KEMERICH, P. D. C.; BORBA, W. F.; SILVA, R. F.; BARROS, G.; GERHARDT, A. E.; FLORES, C. E. B. Valores anômalos de metais pesados em solo de cemitério. Ambi-Agua, Taubaté, v. 7, n. 1, p. 140-156, 2012. (http://dx.doi.org/10.4136/ambi-agua.838)

\subsection{Cobre}

A Figura 5 apresenta os teores de Cobre na área ocupada pelo cemitério São João Batista nos pontos P1 a P10 nas profundidades 0,50 e $100 \mathrm{~cm}$. Todos os pontos amostrados, exceto na amostra superficial $(0 \mathrm{~cm})$ do ponto 4 (em que a concentração foi menor que o Limite de Detecção - L.D), excederam os valores estabelecidos pela Resolução CONAMA no 420/2009, que apresenta $60 \mathrm{mg} \mathrm{kg}^{-1}$ como valor máximo permitido.

O cobre pode ser encontrado na natureza na forma elementar ou na forma de sais, na crosta terrestre ou nos oceanos. A quantidade de cobre encontrada no corpo humano varia de 100 a 150 mg, e sua ingestão diária está entre 2 e 3 mg. Nos seres humanos, Santana (2009) afirmou que a contaminação por cobre causa uma disfunção genética conhecida como Doença de Wilson. O processo de contaminação geralmente ocorre em feto cuja mãe apresenta altas concentrações deste elemento no organismo. A Doença de Wilson provoca um acúmulo excessivo desse elemento essencial no organismo. Em pessoas saudáveis o excesso deste elemento presente em alimentos é eliminado, mas nos doentes de Wilson ocorre uma bioacumulação. No solo é encontrado entre 2 e $100 \mathrm{mg} \mathrm{kg}^{-1}$ de Cobre, já na água potável a concentração dever ser entre 0,01 a $1 \mathrm{mg} \mathrm{L}^{-1}$ (Marques et al., 2003). Contudo, o cobre é considerado um elemento fitotóxico, isso por que é mais tóxico para plantas do que para animais (Costa, 2005).
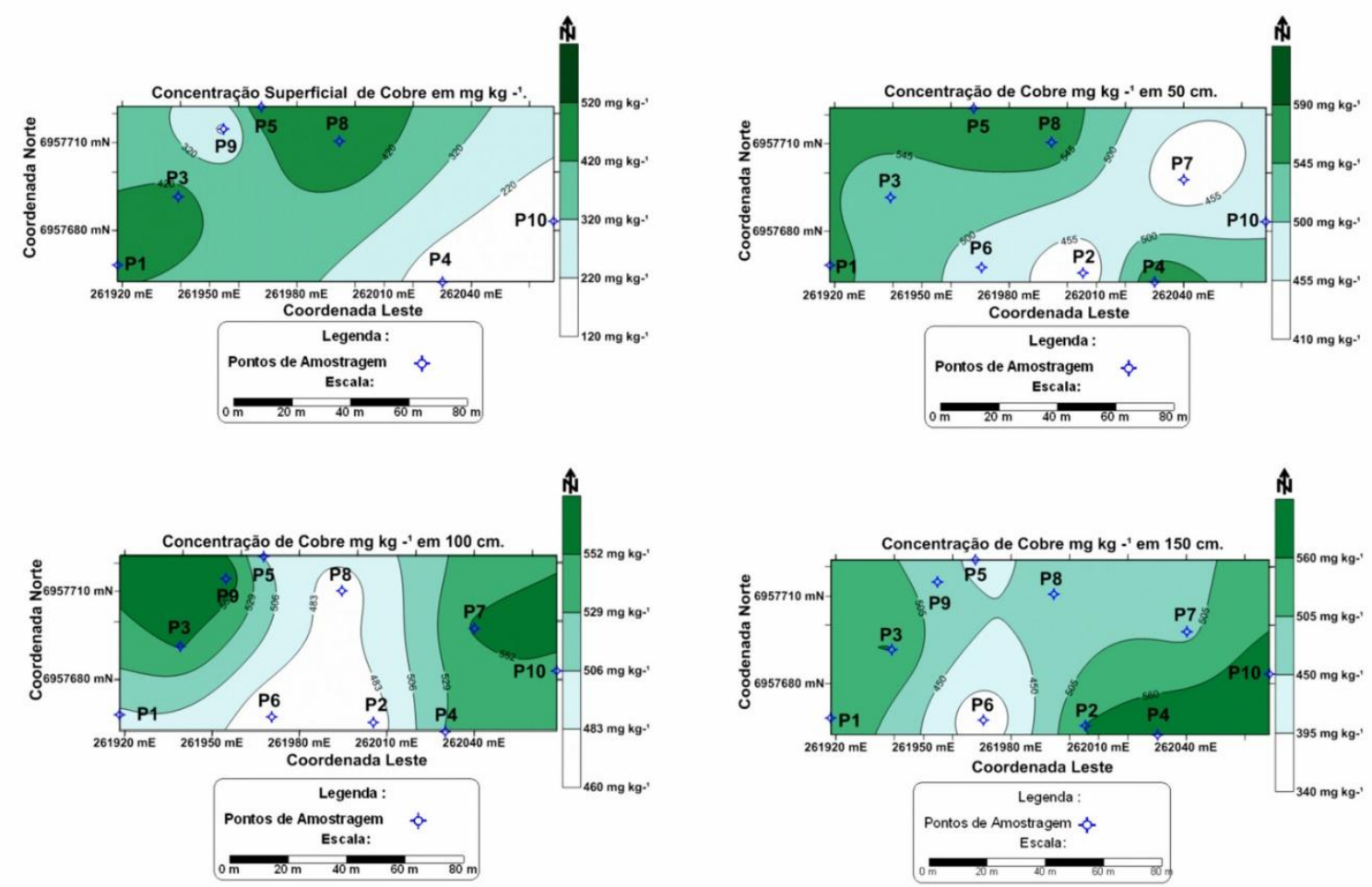

Figura 5. Concentração de Cobre no Cemitério São João Batista nas profundidades entre 0 e $150 \mathrm{~cm}$.

$\mathrm{Na}$ profundidade $0 \mathrm{~cm}$, os maiores valores econtram-se na região norte e oeste do cartograma, já os menores estão na região sudeste (Figura 5). Para a profundidade $50 \mathrm{~cm}$, os maiores valores situam-se na região norte do cartograma, e os menores nas regiões leste e sul. Em $100 \mathrm{~cm}$ os maiores valores encontram-se nas regiões leste e noroeste, e as menores concentrações estão nas regiões norte e sul. Em $150 \mathrm{~cm}$, os maiores valores encontram-se na região sudeste do cartograma, e os menores estão na região sudoeste.

A concentração dos metais pesados nas profundidades variando de $200 \mathrm{~cm}$ a $300 \mathrm{~cm}$, sendo essas profundidades encontradas abaixo das sepulturas cavadas no cemitério (Figura 6). 
KEMERICH, P. D. C.; BORBA, W. F.; SILVA, R. F.; BARROS, G.; GERHARDT, A. E.; FLORES, C. E. B. Valores anômalos de metais pesados em solo de cemitério. Ambi-Agua, Taubaté, v. 7, n. 1, p. 140-156, 2012. (http://dx.doi.org/10.4136/ambi-agua.838)

Na profundidade de $200 \mathrm{~cm}$ o maior valor encontrado situa-se na região sudeste do cartograma, já os menores valores ocorreram nas regiões norte e sul. O cobre na profundidade $250 \mathrm{~cm}$ teve o maior valor no ponto 5 a uma concentração de $560,80 \mathrm{mg} \mathrm{kg}^{-1}$ e altitude de 520,887 m, no cartograma as maiores concentrações estão presentes na região noroeste.

Os menores valores encontraram-se no ponto 3 com concentração de $464,92 \mathrm{mg} \mathrm{kg}^{-1} \mathrm{e}$ altitude de 521,5 m, no cartograma estão representados nas regiões oeste e sudoeste.

Na profundidade de $300 \mathrm{~cm}$, os maiores valores de cobre estão no ponto $8 \mathrm{com} \mathrm{594,56}$ $\mathrm{mg} \mathrm{kg}^{-1}$, na altitude de 518,7 m, localizado na região norte da Figura 6 . O menor valor de cobre foi determinado no ponto 9 , esse ponto está a uma altitude de 518,7 m. No cartograma as menores concentrações em $300 \mathrm{~cm}$ encontram-se na região oeste, no ponto 3 . De forma geral, em todas as profundidades avaliadas, o maior valor de cobre foi no ponto 4 a $150 \mathrm{~cm}$.
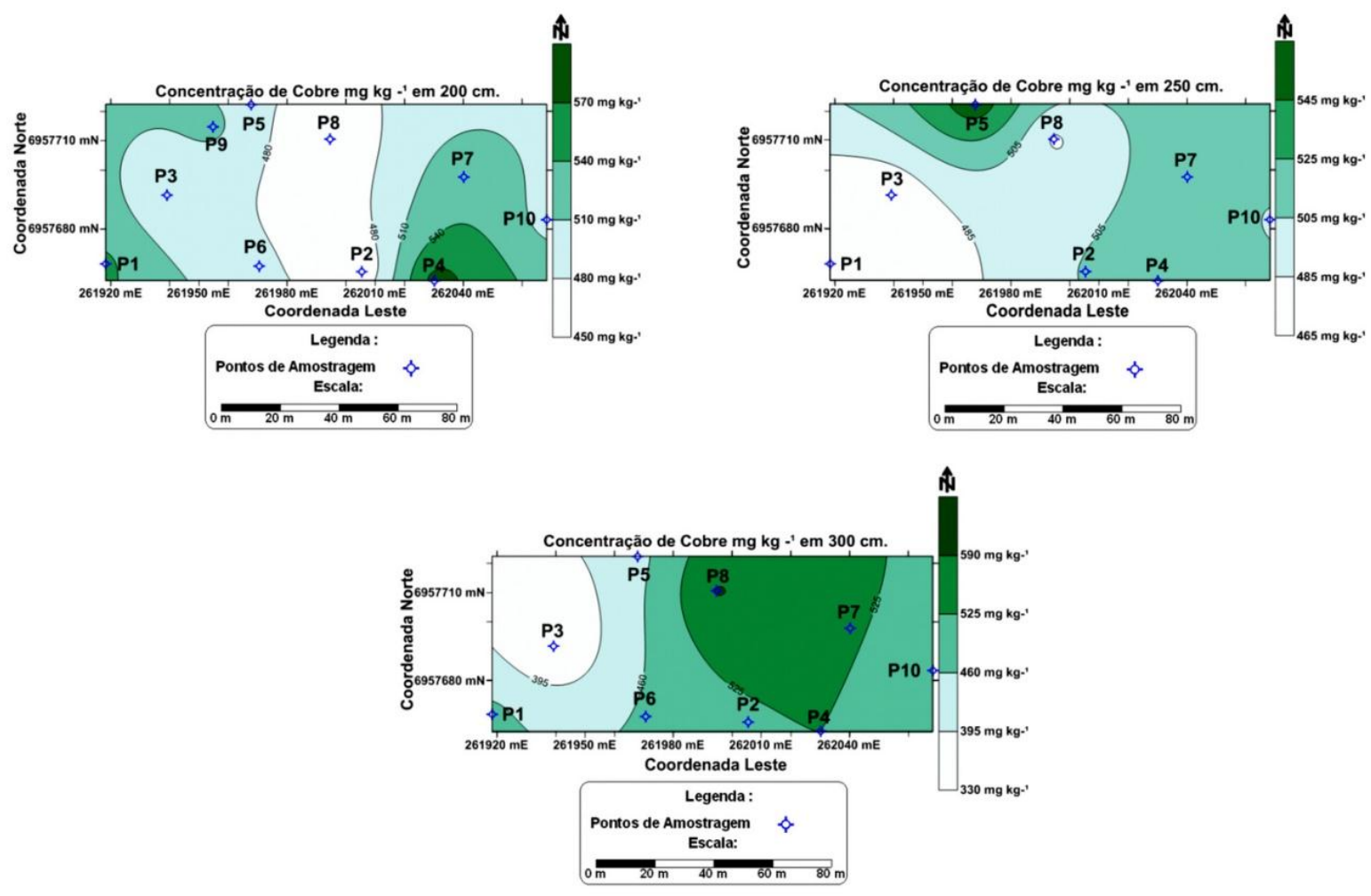

Figura 6. Concentração de Cobre no Cemitério São João Batista nas profundidades entre 200 e $300 \mathrm{~cm}$.

A Figura 7 (a) ilustra a concentração média de Cobre nos 10 diferentes pontos de amostragem, sendo os maiores valores médios encontrados no ponto 8 , coincidindo com o fluxo preferencial da água superficial, cuja concentração varia de 400 a $650 \mathrm{mg} \mathrm{kg}^{-1}$, já os menores valores médios foram encontrados no ponto 9 , com concentração que variou de 150 a $350 \mathrm{mg} \mathrm{kg}^{-1}$. A Figura 7 (b) ilustra a concentração média de Cobre em 7 diferentes profundidades, sendo os maiores valores médios presentes na profundidade $100 \mathrm{~cm}$ a uma concentração que variou de 400 a $600 \mathrm{mg} \mathrm{kg}^{-1}$, já as menores concentrações médias encontraram-se na profundidade $0 \mathrm{~cm}$ com uma variação de 150 a $350 \mathrm{mg} \mathrm{kg}^{-1}$. No intervalo de 100 a $200 \mathrm{~cm}$ estão presentes os maiores valores médios, sendo que os corpos são enterrados entre 200 e $300 \mathrm{~cm}$. 
KEMERICH, P. D. C.; BORBA, W. F.; SILVA, R. F.; BARROS, G.; GERHARDT, A. E.; FLORES, C. E. B. Valores anômalos de metais pesados em solo de cemitério. Ambi-Agua, Taubaté, v. 7, n. 1, p. 140-156, 2012. (http://dx.doi.org/10.4136/ambi-agua.838)

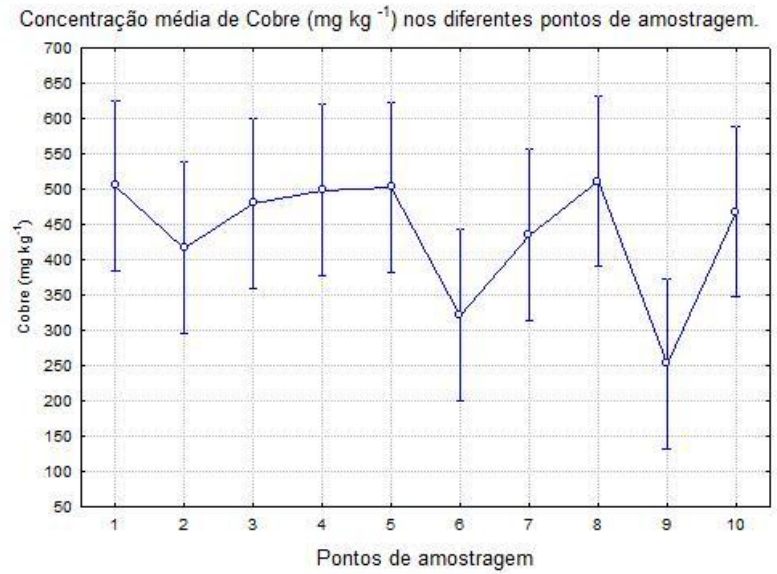

(a)

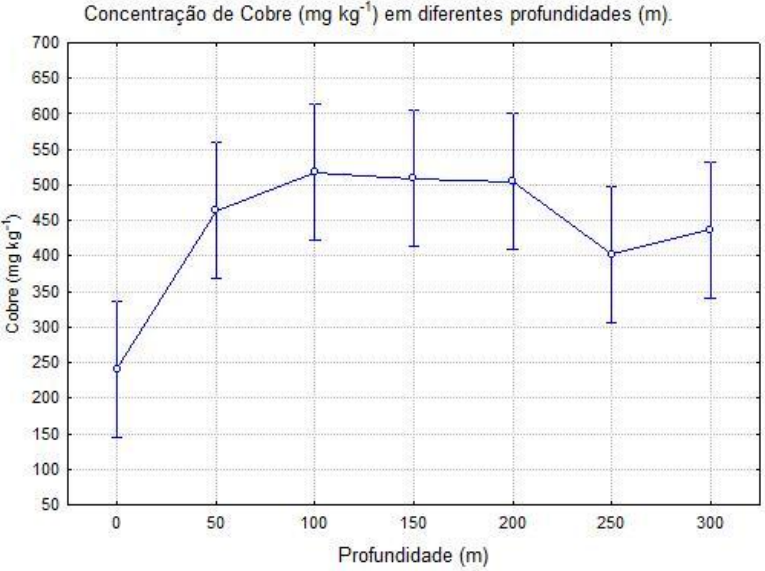

(a)

Figura 7. Concentração média de Cobre em 10 pontos de amostragens (a), concentração média de Cobre em 7 diferentes profundidades (b).

\subsection{Cromo}

A Figura 8 apresenta a variação da concentração de Cromo na área ocupada pelo cemitério São João Batista entre os pontos P1 e P10 nas profundidades 0, 50 e $100 \mathrm{~cm}$. Nessa área apenas amostra superficial do P2 e $50 \mathrm{~cm}$ do P7 não ultrapassaram a concentração permitida pela Resolução CONAMA no $420 / 2009$ para solos $\left(75 \mathrm{mg} \mathrm{kg}^{-1}\right)$.

O cromo é um elemento traço essencial, mas também pode ser tóxico para o ser humano. Este elemento químico é encontrado naturalmente no solo, na poeira e gases de vulcões. No meio ambiente, pode ser encontrado na forma de cromo (0), cromo (III) e cromo (VI), sendo que o cromo (III) tem ocorrência natural no meio ambiente, enquanto cromo (VI) e cromo (0) são geralmente produzidos por processos industriais.

A presença de cromo nas águas subterrâneas está associada à contaminação de origem antrópica, de acordo com sua concentração pode apresentar-se como um elemento essencial e tóxico, ou não. Enquanto o Cr (III) é um elemento essencial e tóxico em nível de traço em animais o $\mathrm{Cr}$ (VI), é não essencial e tóxico em baixas concentrações. Em função dos processos de oxirredução, de transformação de Cr (III) em Cr (VI) e vice-versa, consideramse as atividades antropogênicas que liberam o $\mathrm{Cr}$ (III) ou o $\mathrm{Cr}$ (VI) como indesejáveis, mesmo se Cr (III) seja descarregado no meio ambiente, não há garantia de que ele permanecerá neste estado químico (Mâcedo, 2004).

$\mathrm{O}$ cromo no solo está em sua maioria na forma de óxido insolúvel $\mathrm{Cr}_{2} \mathrm{O}_{3}$ de baixa mobilidade e uma pequena quantidade nas formas solúveis de $\mathrm{Cr}$ (VI) e $\mathrm{Cr}$ (III), portanto de maior mobilidade no solo. A mobilidade destas formas depende das características de adsorção do solo como teor de argila, teor de $\mathrm{Fe}_{2} \mathrm{O}_{3}$ e matéria orgânica (Schirmer et al., 2009)

$\mathrm{O}$ elemento químico cromo é extremamente usado na galvanoplastia e na indústria de curtumes. Todos esses processos geram como consequência, efluentes líquidos, resíduos sólidos e emissões gasosas, com considerável grau de toxicidade e que necessitam de tratamento específico (Mota Sobrinho et al., 2007). 

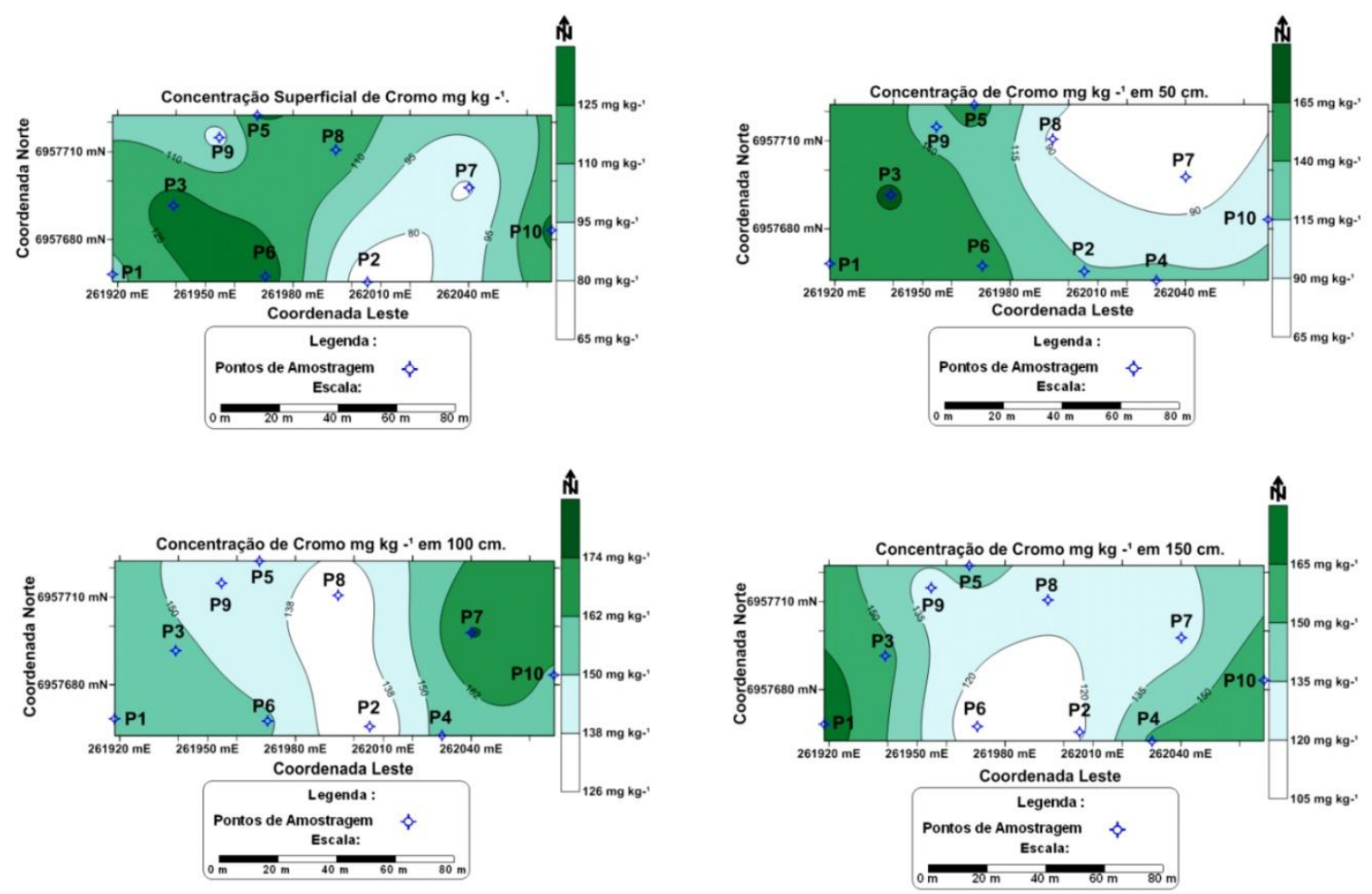

Figura 8. Concentração de Cromo no Cemitério São João Batista nas profundidades entre 0 e $150 \mathrm{~cm}$.

$\mathrm{Na}$ profundidade $0 \mathrm{~cm}$ os maiores valores econtram-se nas regiões sudeste, sudoeste e norte do cartograma, as menores concentrações estão nas regiões leste e sul (Figura 8). Para a profundidade $50 \mathrm{~cm}$ os maiores valores situam-se na região oeste, enquanto que os menores estão representados nas regiões leste e nordeste. Em $100 \mathrm{~cm}$ os maiores valores encontram-se na região nordeste e os menores estão nas regiões central, norte e sul. Em $150 \mathrm{~cm}$ os maiores valores estão na região sudoeste e os menores na região sul.

A Figura 9 ilustra as concentrações de cromo nas profundidades variando de 200 a 300 $\mathrm{cm}$. Na profundidade de $200 \mathrm{~cm}$ os maiores valores estão nas regiões noroeste e oeste, já os menores encontran-se na região sul do cartograma. Na profundidade de $250 \mathrm{~cm}$ o maior valor de cromo foi no no ponto 3 a uma concentração de $193,75 \mathrm{mg} \mathrm{kg}^{-1}$ e altitude de $521,5 \mathrm{~m}$, no cartograma as maiores concentrações de cromo em $250 \mathrm{~cm}$ estão presentes na região noroeste. Os menores valores foram encontrados no ponto 8 com $82,02 \mathrm{mg} \mathrm{kg}^{-1}$ e altitude de $518,7 \mathrm{~m}$, no cartograma encontram-se na região norte.

Na profundidade de $300 \mathrm{~cm}$ o maior valor esteve presente no ponto 1 a uma concentração de $280,12 \mathrm{mg} \mathrm{kg}^{-1}$ e altitude de $522,6 \mathrm{~m}$, no cartograma as maiores concentrações estão na região sudoeste. $\mathrm{O}$ menores valores observados para cromo em $300 \mathrm{~cm}$ foram encontrados no ponto $2\left(124,01 \mathrm{mg} \mathrm{kg}^{-1}\right)$ e altitude de $522,16 \mathrm{~m}$, no cartograma as menores concentrações estão apresentadas nas regiões norte, sul e nordeste. O menor valor de cromo encontrado em todas as profundidades foi na amostra superficial do ponto 4 , já o maior valor foi encontrado no ponto $1 \mathrm{em} 300 \mathrm{~cm}$. 
KEMERICH, P. D. C.; BORBA, W. F.; SILVA, R. F.; BARROS, G.; GERHARDT, A. E.; FLORES, C. E. B. Valores anômalos de metais pesados em solo de cemitério. Ambi-Agua, Taubaté, v. 7, n. 1, p. 140-156, 2012. (http://dx.doi.org/10.4136/ambi-agua.838)
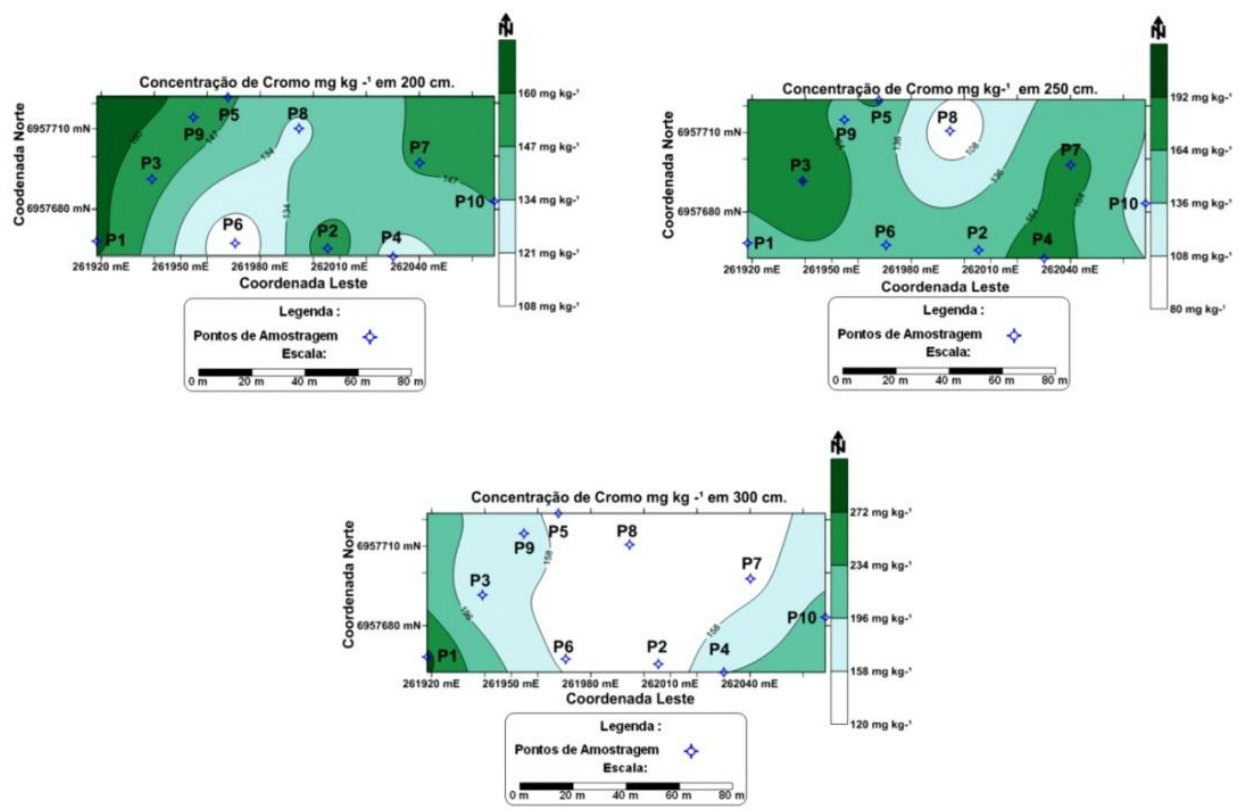

Figura 9. Concentração de Cromo no Cemitério São João Batista nas profundidades entre 200 e $300 \mathrm{~cm}$.

A Figura 10 (a) ilustra a concentração média de Cromo nos 10 diferentes pontos de amostragem, sendo os maiores valores médios encontrados no ponto $1 \mathrm{com}$ concentração que varia de 140 a $190 \mathrm{mg} \mathrm{kg}^{-1}$, já os menores valores médios foram encontrados no ponto 8 cuja concentração variou de 90 a $140 \mathrm{mg} \mathrm{kg}^{-1}$. A Figura 10 (b) ilustra a concentração média de Cromo em 7 diferentes profundidades, sendo os maiores valores médios presentes na profundidade $300 \mathrm{~cm}$ a variando de 150 a $190 \mathrm{mg} \mathrm{kg}^{-1}$, já as menores concentrações médias encontram-se na profundidade $0 \mathrm{~cm}$ com variação de 80 a $120 \mathrm{mg} \mathrm{kg}^{-1}$. O ponto 1 tem um menor influência do fluxo preferencial, pois está localizado no ponto mais alto do terreno, já o ponto 8 está sobre forte influência do escoamento superficial.

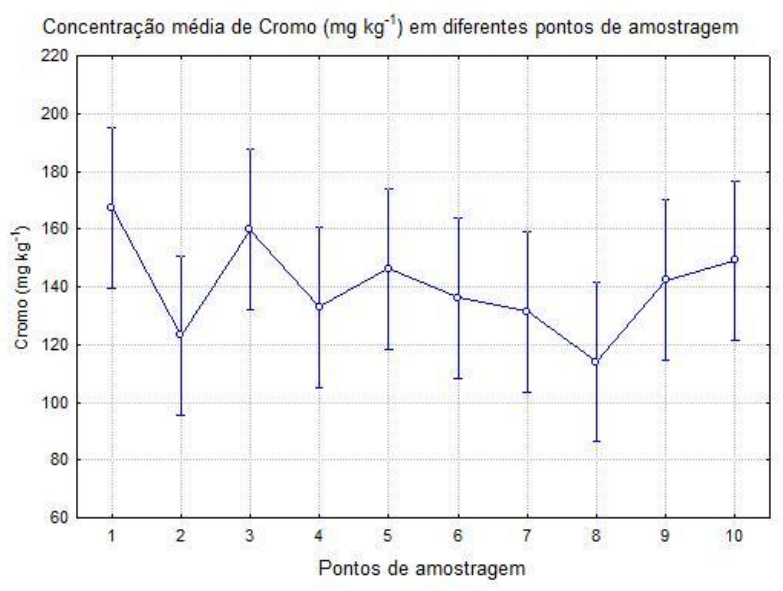

(a)

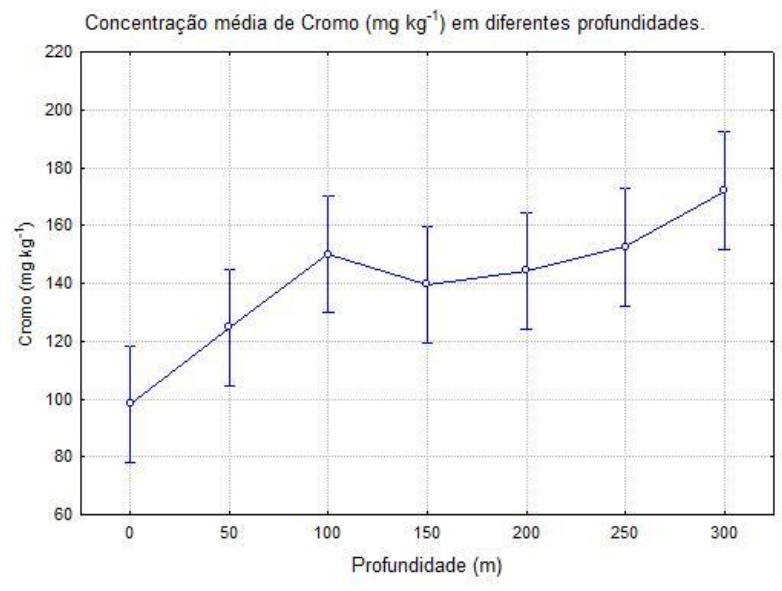

(b)

Figura 10. Concentração média de Cromo em 10 pontos de amostragens (a), concentração média de Cromo em 7 diferentes profundidades (b). 
KEMERICH, P. D. C.; BORBA, W. F.; SILVA, R. F.; BARROS, G.; GERHARDT, A. E.; FLORES, C. E. B. Valores anômalos de metais pesados em solo de cemitério. Ambi-Agua, Taubaté, v. 7, n. 1, p. 140-156, 2012. (http://dx.doi.org/10.4136/ambi-agua.838)

\subsection{Zinco}

A Figura 11 apresenta a variação da concentração de zinco na área ocupada pelo cemitério São João Batista entre os pontos P1 e P10 nas profundidades 0, 50, 100 e $150 \mathrm{~cm}$. $\mathrm{Na}$ área estudada, considerando todos os 10 pontos amostrados, as concentrações dos metais ultrapassaram os valores estabelecidos pela Resolução CONAMA n ${ }^{\circ}$ 420/2009 para solos $\left(300 \mathrm{mg} \mathrm{kg}^{-1}\right)$.

O zinco é considerado o $25^{\circ}$ elemento mais abundante na crosta terrestre, ocorre em vários minerais e em diferentes formas (sulfetos ou carbonatos de $\mathrm{Zn}$ ), seu maior uso é na galvanização de produtos de ferro $(\mathrm{Fe})$, proporcionando uma cobertura resistente à corrosão. É utilizado em baterias, fertilizantes, aros e rodas de veículos, tintas, plásticos, borrachas, em alguns cosméticos como pós e bases faciais e produtos farmacêuticos, como os complexos vitamínicos (Moore e Ramamoorthy, 1984). A absorção excessiva do metal pelo organismo pode levar a um quadro de intoxicação, resultando em sintomas como vômitos, diarréias e cólicas (Bona et al., 2007).

$\mathrm{Na}$ profundidade $0 \mathrm{~cm}$, os maiores valores econtram-se na regiões norte e sudoeste do cartograma, já os menores estão na região noroeste. Para a profundidade $50 \mathrm{~cm}$ os maiores valores situam-se na regiões norte e sudeste, e os menores estão nas regiões leste, sul e oeste. Em $100 \mathrm{~cm}$ os valores de maior concentração estão na região leste, já os de menores estão representados nas regiões oeste e sudeste. Em $150 \mathrm{~cm}$, os maiores valores encontrados estao localizados na região sudeste e os menores nas regiões noroeste e sudeste.
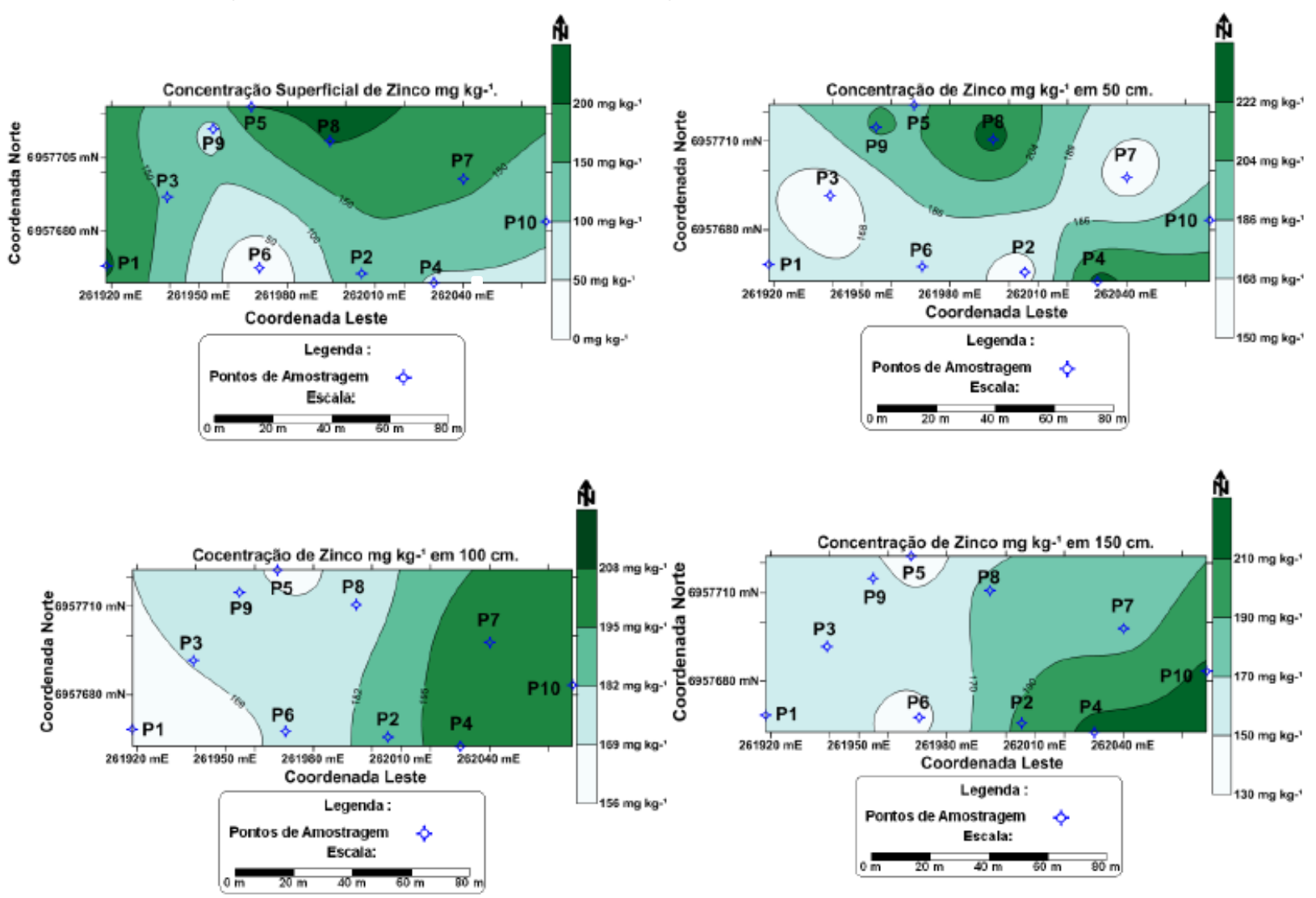

Figura 11. Concentração de Zinco no Cemitério São João Batista nas profundidades entre 0 e $150 \mathrm{~cm}$.

A Figura 12 ilustra a distribuição das concentrações dos metais pesados nas profundidades variando de 200 a $300 \mathrm{~cm}$, profundidades essas abaixo das covas utilizadas para os sepultamentos no cemitério. Na profundidade de $200 \mathrm{~cm}$, os maiores valores encontrados situam-se nas regiões sudeste e sudoeste do cartograma, já os menores valores 
KEMERICH, P. D. C.; BORBA, W. F.; SILVA, R. F.; BARROS, G.; GERHARDT, A. E.; FLORES, C. E. B. Valores anômalos de metais pesados em solo de cemitério. Ambi-Agua, Taubaté, v. 7, n. 1, p. 140-156, 2012. (http://dx.doi.org/10.4136/ambi-agua.838)

ocorreram na região sul. $\mathrm{O}$ zinco na profundidade $250 \mathrm{~cm}$ teve o maior valor no ponto $10 \mathrm{a}$ uma concentração de $204,57 \mathrm{mg} \mathrm{kg}^{-1}$ e altitude de $518,0 \mathrm{~m}$, no cartograma as maiores concentrações estão nas regiões leste e noroeste. $\mathrm{O}$ menor valor encontra-se no ponto 3 com concentração de $117,41 \mathrm{mg} \mathrm{kg}^{-1}$ e altitude de $521,5 \mathrm{~m}$, no cartograma as menores concentrações localizam-se na região oeste.

$\mathrm{Na}$ profundidade $300 \mathrm{~cm}$ tem-se como valor máximo de zinco no ponto $8 \mathrm{com}$ a concentração de $219,12 \mathrm{mg} \mathrm{kg}^{-1}$ e altitude de $518,7 \mathrm{~m}$, no cartograma os maiores valores localizam-se na região norte. O menor valor encontra-se no ponto 3 a uma altitude de $521,5 \mathrm{~m}$ e concentração de $91,63 \mathrm{mg} \mathrm{kg}^{-1}$, no cartograma as menores concentrações estão representadas na região oeste. $\mathrm{O}$ menor valor encontrado para zinco esteve na amostra superficial do ponto 6 , já o maior esteve no ponto 8 , em uma profundidade de $50 \mathrm{~cm}$.

A Figura 13 (a) ilustra a distribuição das concentrações médias de Zinco nos 10 diferentes pontos de amostragem, sendo os maiores valores médios encontrados no ponto $4 \mathrm{e}$ no ponto 8 com concentração que variou de 170 a $210 \mathrm{mg} \mathrm{kg}^{-1}$, já os menores valores médios foram encontrados no ponto 6 a uma concentração que variou de 110 a $160 \mathrm{mg} \mathrm{kg}^{-1}$. A Figura 13 (b) ilustra a concentração média de Zinco em 7 diferentes profundidades, sendo os maiores valores médios presentes na profundidade $50 \mathrm{~cm}$ a uma concentração que varia de 165 a 210 mg kg ${ }^{-1}$, já as menores concentrações médias encontram-se na profundidade $0 \mathrm{~cm}$ com uma variação de 110 a $160 \mathrm{mg} \mathrm{kg}^{-1}$.

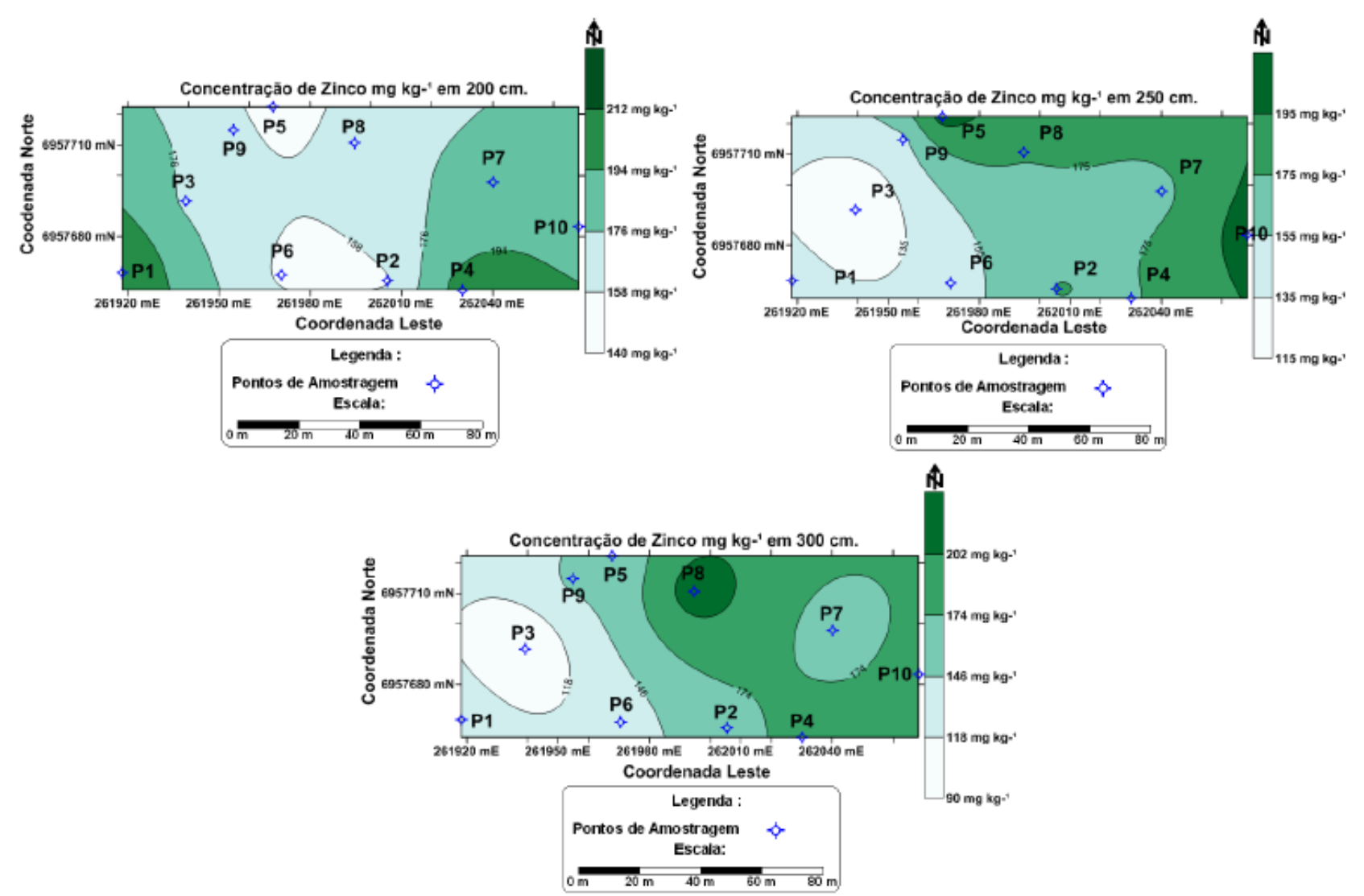

Figura 12. Concentração de Zinco no Cemitério São João Batista nas profundidades entre 200 e $300 \mathrm{~cm}$. 
KEMERICH, P. D. C.; BORBA, W. F.; SILVA, R. F.; BARROS, G.; GERHARDT, A. E.; FLORES, C. E. B. Valores anômalos de metais pesados em solo de cemitério. Ambi-Agua, Taubaté, v. 7, n. 1, p. 140-156, 2012. (http://dx.doi.org/10.4136/ambi-agua.838)

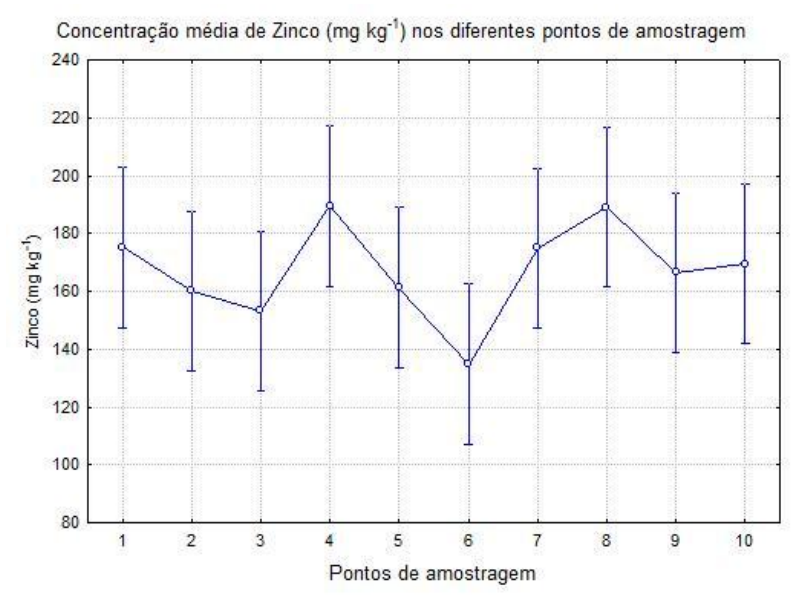

(a)

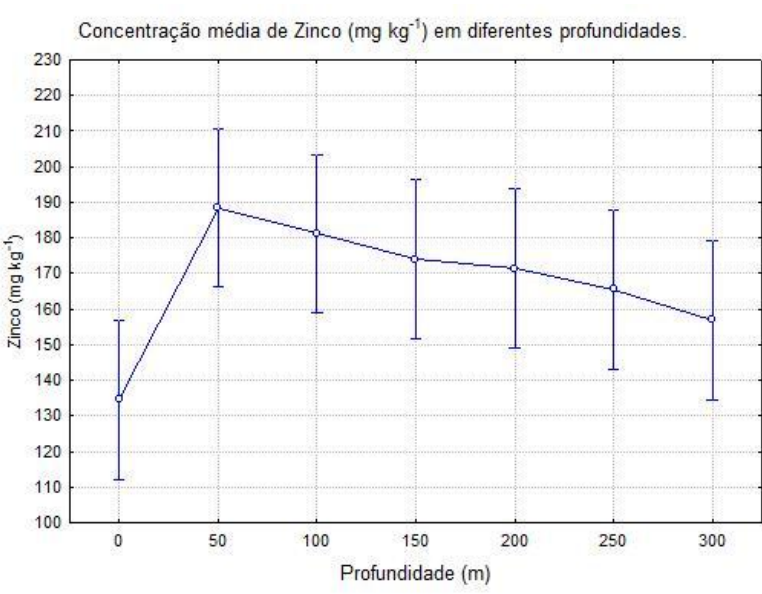

(b)

Figura 13. Concentração média de Zinco em 10 pontos de amostragens (a), concentração média de Zinco em 7 diferentes profundidades (b).

\section{CONCLUSÃO}

Os metais Bário e Cobre apresentaram concentrações elevadas, indicando contaminação do solo em todos os pontos amostrados, já o elemento Cromo apresentou indícios de contaminação nas profundidades variando entre 1 a 3 metros. Para o elemento Zinco os valores ficaram abaixo do valor estabelecido como máximo pela legislação brasileira em todos os pontos amostrados.

\section{REFERÊNCIAS}

ANJOS, R. M. Cemitérios: uma ameaça à saúde humana. In: CONGRESSO BRASILEIRO DE ENGENHARIA SANITÁRIA E AMBIENTAL, 24., 02-07 setembro 2007, Belo Horizonte. Anais... Belo Horizonte: ABES, 2007. 1 CD-ROM.

BONA, I. A. T.; SARKIS, J. E. S.; SALVADOR, V. L. R.; SOARES, A. L. R.; KLAMT, S. L. Análise arqueométrica de cerâmica Tupiguarani da região central do Estado do Rio Grande do Sul, Brasil, usando fluorescência de raios $\mathrm{X}$ por disperção de energia (EDXRF). Revista Química Nova, São Paulo, n. 30, p. 785-790, jan./fev. 2007.

BRASIL. Conselho Nacional do Meio Ambiente. Resolução no 420, de 28 de Dezembro de 2009. Dispõe sobre os critérios e valores orientadores de qualidade do solo quanto à presença de substâncias químicas e estabelece diretrizes para o gerenciamento ambiental de área contaminada por essas substâncias em decorrência de atividades antrópicas. Brasília, 2009. Disponível em: <http://homologa.ambiente.sp.gov.br/aquiferos/ CONAMA\%20Resolucao\%202009_420.pdf>. Acesso em: 15 fev. 2011.

BRASIL. Conselho Nacional do Meio Ambiente. Resolução no 335, de 3 de abril de 2003. Dispõe sobre o licenciamento ambiental de cemitérios. Brasília, 2003. Disponível em: <http://www.mma.gov.br/port/conama/res/res03/res33503.xml>. Acesso em: 16 abril 2012.

COSTA, C. das N. Biodisponibilidade de metais pesados em solos do Rio Grande doSul. 2005. 126f. Tese (Doutorado em Ciência do Solo) - Universidade Federal do Rio Grande do Sul, Porto Alegre, 2005. 
KEMERICH, P. D. C.; BORBA, W. F.; SILVA, R. F.; BARROS, G.; GERHARDT, A. E.; FLORES, C. E. B. Valores anômalos de metais pesados em solo de cemitério. Ambi-Agua, Taubaté, v. 7, n. 1, p. 140-156, 2012. (http://dx.doi.org/10.4136/ambi-agua.838)

FILIZOLA, H. F.; FERRACINI, V. L.; SANS, L. M. A.; GOMES, M. A. F.; FERREIRA, C. J. A. Monitoramento e avaliação do risco de contaminação por pesticidas em água superficial e subterrânea na região de Guaira. Pesquisa Agropecuária Brasileira, Brasília, v. 37, n. 5, p. 659-667, maio/jun. 2002.

HAN X. Y.; ZHUO, S. J.; SHEN, R. X.; WANG, P. L.; JI A. Comparison of the quantitative results corrected by fundamental parameter method and difference calibration specimens in x-ray fluorescence spectrometry. Journal of Quantitative Spectroscopy and Radiative Transfer, v. 97, n. 1, p. 68-74, 2006.

http://dx.doi.org/10.1016/j.jqsrt.2004.12.018

INSTITUTO BRASILEIRO DE GEOGRAFIA E ESTATÍSTICA - IBGE. Contagem da população. 2009. Disponível em: <http://www.ibge.gov.br>. Acesso em: 15 maio de 2011.

KABATA-PENDIAS, A.; PENDIAS, H. Trace elements in soil and plants. Boca Raton: CRC Press, 1992. 365 p.

MÂCEDO, J. A. B. Águas \& águas. 2. ed. Belo Horizonte: CRQ-MG, 2004.

MARQUES, J. F.; SKOPURA, L. A.; FERRAZ, J. M. G. Indicadores de sustentabilidade em agroecossistemas. Jaguariuna: Embrapa Meio Ambiente, 2003.

MARTINS, M. T.; PELliZARI, V. H.; PACHECO, A.; MYAKI, D. M.; ADAMS, C.; BOSSOLAN, N. R. S. et al. Qualidade bacteriológica de água subterrânea em cemitérios. Revista Saúde Pública, São Paulo, v. 25, n. 1, p. 47-52, jan./fev. 1991.

MOORE, J. W.; RAMAMOORTHY, S. Heavy metals in natural waters. New York: Springer-Verlag, 1984. http://dx.doi.org/10.1007/978-1-4612-5210-8

MOTA SOBRINHO, M. A. da; OLIVIER, S.; SILVA, V. L. Metodologia para extração de cromo de lodo galvânico. In: CONGRESSO BRASILEIRO DE ENGENHARIA SANITÁRIA E AMBIENTAL, 24., 02-07 setembro 2007, Belo Horizonte. Anais... Belo Horizonte: ABES, 2007. 1 CD-ROM.

NEIRA, D. F.; TERRA, V. R.; SANTOS, R. P.; BARBIÉRI, R. S. Impactos do necrochorume nas águas subterrâneas do cemitério de Santa Inês, Espírito Santo, Brasil. Natureza On Line, Santa Teresa, v. 6, p. 36-41, jan./fev. 2008.

SANTANA, G. P. Contaminação por cobre: a doença de Wilson. 2009. Disponível em: <http://www.cq.ufam.edu.br/Artigos/cobre/contaminacao_cobre.html>. Acesso em: 3 abril 2012.

SCHIRMER, W. N.; DREIFUS, T. V.; QUARTAROLI, L.; BENATTO, G. L.; OLIVEIRA, G. L.; VANZETO, S. A química ambiental do cromo e seus compostos. In: SEMANA DE ENGENHARIA AMBIENTAL, 7., 01-04 junho 2009, Irati. Anais... Irati: EESC/USP, 2009. 1 CD ROM,.

SILVA, R. W. da C.; MALAGUTTI FILHO, W. Emprego do imageamento elétrico no estudo da contaminação por cemitérios. Revista Geociências, Porto Alegre, v. 29, p. 343354, jan./fev. 2010.

SILVA, R. W. da C.; MALAGUTTI FILHO, W. Cemitérios como áreas potencialmente contaminadas. Revista Brasileira de Ciências Ambientais, Cubatão, v. 9, p. 26-35, mar./abr. 2008. 
KEMERICH, P. D. C.; BORBA, W. F.; SILVA, R. F.; BARROS, G.; GERHARDT, A. E.; FLORES, C. E. B. Valores anômalos de metais pesados em solo de cemitério. Ambi-Agua, Taubaté, v. 7, n. 1, p. 140-156, 2012. (http://dx.doi.org/10.4136/ambi-agua.838)

TEIXEIRA, S. A. Medicina holística: a harmonia do ser humano. Rio de Janeiro: Campus, 2003.

VENDRAME, I. F.; MEDEIROS, G. A.; BRESSAN, M. A. Estudo da poluição de águas subterrâneas em nível local. In: ENCONTRO DE INICIAÇÃO CIENTÍFICA E PÓSGRADUAÇÃO DO ITA, 9., outubro 2003, São José dos Campos. Anais... São José dos Campos: ITA, 2003. v. 1. p. 1. 